\title{
Eastern Ukrainian Medical Journal
}

\author{
2, Rymskogo-Korsakova st., Sumy 40007 , Ukraine \\ eumj.med.sumdu.edu.ua \\ e-mail: EUMJ@med.sumdu.edu.ua \\ ISSN: 2663-5909 (print)
}

УДК 616-083.98:364.632:331

DOI: https://doi.org/10.21272/eumj.2019;7(4):351-357

\section{Abstract}

'Yu. V. Shkatula,

'Y. O. Badion,

${ }^{2}$ M. V. Novikov,

'Ya. V. Khyzhnia,

'Sumy State University, 2, Rymskoho-Korsakova st, Sumy, Ukraine 40007;

${ }^{2}$ Sumy Regional Centre for Emergency Medical Care and disaster Medicine, Hromadiansky Lane, 4a, Sumy, Ukraine, 40021

\section{EMERGENCY MEDICINE: PROBLEMS OF VIOLENCE AND SAFETY AT WORK}

The work of medical workers is associated with constant psychoemotional stress, which is caused by close contact with human suffering, the need to make immediate decisions, uncomfortable conditions of the pre-hospital stage and cases of aggressive and violent actions by patients or third parties.

Statistics show that 54 to $84.8 \%$ of medical workers have become victims of verbal or physical aggression annually. In 2013-2017, 543 crimes against life and health of medical workers on duty were registered in Ukraine.

The purpose of the research was to study the causes, nature and risk factors of violent actions against emergency medical personnel with finding the ways to normalize the situation.

Material and methods. An anonymous non-personified survey was conducted among 127 workers of the Sumy Regional Centre for Emergency Medical Care and Disaster Medicine. A modified questionnaire "Violence and aggression in the Health Service" (B. Mullan, F. Badger, 2007) was used in the study.

It has been established that $74.8 \%$ of emergency medical care and disaster medicine personnel were victims of violence caused by patients, their relatives or friends. Most often, the reasons for aggressive behaviour of the patient or third parties were the time of waiting for a medical worker and the suspicion of incompetence.

According to the results of the survey, $35.43 \%$ of employees believe that it is possible to improve the situation by completing and forming ambulance teams of a mixed type. Almost a third of the surveyed medical workers $(24.41 \%)$ indicated the need to provide personal protective equipment, another $14.96 \%$ of respondents wanted better legal support and assistance.

The authors come to the conclusion that it is necessary to solve the problem of the safety of a medical worker during an emergency call at the state legislative level. Particular attention should be paid to the further improvement of legal assistance, as well as to the development of measures to prevent violence.

Key words: emergency services, workplace violence, protection. 


\section{Резюме}

1Ю. В. Шкатула,

1Ю. О. Бадіон,

${ }^{2}$ М. В. Новіков,

'Я. В. Хижня,

${ }^{1}$ Сумський державний університет, вул. Римського-Корсакова, 2, м. Суми, Україна ,40007;

${ }^{2}$ КЗ СОР «Сумський обласний иентр екстренної медичної допомоги та медицини катастроф», Громадянський провулок, 4а, м. Суми, Украӥна, 40021

\section{ЕКСТРЕНА МЕДИЧНА ДОПОМОГА: ПРОБЛЕМА НАСИЛЬСТВА ТА БЕЗПЕКИ НА РОБОЧОМУ МІСЦІ}

Робота працівників служби екстреної медичної допомоги пов'язана 3 постійним психо-емоційним напруженням, що обумовлено тісним контактом $з$ людським стражданням, необхідністю прийняття негайних рішень, некомфортними умовами догоспітального етапу та випадками агресивно-насильницьких дій з боку пацієнтів або третіх осіб.

Результати статистичних досліджень свідчать, що від 54 до 84,8 \% співробітників служб первинної медико-санітарної допомоги щорічно стають жертвами вербальної або фізичної агресії. В Україні впродовж 2013-2017 років було зареєстровано 543 злочини, вчинені проти життя і здоров'я медичного персоналу при виконанні ними службових обов'язків.

Метою дослідження було вивчення причин, характеру та факторів ризику насильницьких дій по відношенню до співробітників екстреної медичної допомоги 3 визначенням шляхів нормалізації ситуації.

Матеріали і методи. Проведено анонімне неперсоніфіковане анкетування 127 співробітників Сумського обласного центру екстреної медичної допомоги та медицини катастроф. Дослідження проводилося за допомогою модифікованого опитувальника «Violence and aggression in the Health Service» (B. Mullan, F. Badger, 2007).

Результати і їх обговорення. Установлено, що 74,8 \% працівників стали жертвами насильницьких дій з боку пацієнтів, їх родичів або знайомих. Частіше всього причинами агресивної поведінки пацієнта або третіх осіб були час очікування медичного працівника та підозри в його некомпетентності.

За результатами анкетування, 35,43 \% співробітників вважають, що покращити ситуацію можливо повним комплектуванням та формуванням бригад за змішаним типом. Практично третина анкетованих медичних співробітників $(24,41 \%)$ вказали на необхідність забезпечення засобами індивідуального захисту, ще 14,96 \% респондентів бажають покращення юридичної підтримки та правової допомоги.

Автори приходять до висновку, що проблему безпеки медичного працівника при екстреному виклику необхідно вирішувати на державному законодавчому рівні. Особливої уваги потребує подальше вдосконалення правової допомоги, розробка заходів із попередження насилля.

Ключові слова: екстрена медична допомога, насильство на робочому місці, захист.

Автор, відповідальний за листування: y.badion@med.sumdu.edu.ua

\section{Introduction}

The work of emergency medical service employees is associated with constant psychoemotional stress, which is due to close contact with human suffering, the need for immediate decisionmaking, uncomfortable conditions of the prehospital stage and cases of violent acts by patients or third parties. Ultimately, this leads to formation of burnout syndrome with the development of specific psychopathological and psychosomatic symptoms and signs of social dysfunction. Emotional burnout affects performance in the workplace and professional longevity, increases the risk of medical errors $[1,2,3]$. 
Violence has been one of the most topical issues in the workplace for over a decade. The results of statistical studies conducted regularly in the United States of America, Australia, Turkey, China, and Japan show that between 54 and $84.8 \%$ of primary health care workers annually become victims of verbal or physical aggression from patients or their relatives and acquaintances [4, 5, 6, 7].

During 2013-2017, 543 crimes were committed in Ukraine against the life and health of medical personnel on duty, three people died [8]. We assume that there are significantly more such offenses, because medical workers usually do not file lawsuits with the courts, explaining this by insecurity in obtaining proper legal assistance, lack of time, and sometimes refusal to initiate a criminal or administrative case at the pre-trial verification stage.

An analytical review of literature allowed us to find out global trends in improving the situation. Government programs to ensure the safety of medical workers on duty are being implemented in Australia and Canada [3, 9, 10]. A number of countries are moving towards greater responsibility for violence and aggression against medical personnel. In 2015, the Spanish Penal Code (section XXII, paragraph 1, article 550) was amended to equate a medical professional with a civil servant, with a corresponding increase in punishment. In the UK there are "black lists" of potentially dangerous persons, upon visiting which medical workers appear immediately accompanied by police $[11,12,13]$.

Recently, the Law of Ukraine "On emergency medical care" introduced a clause to the article 11: "A worker of the emergency medical care system, which is part of the emergency (ambulance) medical care crew, has the right for protection from unlawful attacks on his life and health while performing his official duties, which is provided in accordance with the law", but this amendment, unfortunately, has no real practical application [14].

Today there are no systematic studies of the nature and frequency of cases of violence and aggression against primary health care workers in Ukraine.

The objective of the study is to study the causes, nature and risk factors of violent acts against emergency medical personnel with the identification of ways to normalize the situation.

\section{Materials and research methods}

An anonymous non-personalized survey of 127 workers of the Sumy Regional Center for Emergency Medical Care and Disaster Medicine was conducted. The survey was conducted using the modified questionnaire "Violence and aggression in the Health Service" (B. Mullan, F. Badger, 2007) [15]. In addition to demographic indicators, the position held and the length of service, a survey was conducted on the frequency, causes and nature of aggressive actions towards a medical worker by a patient or third parties. Besides we tried to find out the level of security that workers experience during an emergency call. We determined it according to a scale from 1 (very safe) to 10 (very dangerous) points.

Statistical processing of the obtained data was carried out using the computer program "Microsoft Excel 2010". The data are presented as arithmetic mean values and the error of the mean $\mathrm{M} \pm \mathrm{m}$. A correlation coefficient ( $r$ ) we used as a criterion of statistical dependence between the studied parameters. To confirm the significant difference, the probability value $\mathrm{p}<0.05$, generally accepted in biomedical research, was taken into account.

\section{Study results and discussion}

127 employees of the Center for Emergency Medicine Care and Disaster Medicine agreed to participate in the study. The total array was 64 $(50.39 \%)$ men and $63(49.61 \%)$ women. The average age of the respondents was $38.1 \pm 1.42$ years. Among our respondents there were 27 $(21.26 \%)$ doctors, $95(74.8 \%)$ paramedics, and 5 (3.94\%) non-medical workers. The distribution of questioned employees depending on the length of service and a position held is shown in table 1.

Table 1 - Distribution of emergency medical personnel depending on the length of service and a position

\begin{tabular}{l|c|c|c|c}
\hline \multirow{2}{*}{ Position } & \multicolumn{4}{c}{ Length of service } \\
\cline { 2 - 5 } & to 2 years & 2-5 years & 5-10 years & over 10 years \\
\hline Doctor & $3 / 2.36$ & $5 / 3.94$ & 0 & $19 / 14.96$ \\
\hline Paramedic & $27 / 21.26$ & $16 / 12.6$ & $9 / 7.09$ & $43 / 33.86$ \\
\hline Supportive personnel & $2 / 1.57$ & $1 / 0.79$ & $1 / 0.79$ & $1 / 0.79$ \\
\hline Total & $32 / 25.2$ & $22 / 17.32$ & $10 / 7.87$ & $63 / 49.61$ \\
\hline
\end{tabular}


The data presented in table 1 show that the largest group consisted of emergency medical workers with length of service of more than 10 years $-49.61 \%$ of the total number of respondents. The second ranking place took a group of health workers with work experience of up to 2 years -32 people, which is $25.2 \%$. The smallest group are employees with work experience of 5 to 10 years $(7.87 \%)$.

In a survey of $95(74.8 \%)$ employees of the regional center of emergency medical care and disaster medicine, they reported that they were victims of violence by patients, their relatives or acquaintances, and 53 respondents noted that there were several such incidents in one year. In total, according to the results of the questionnaire, there occurred 155 offenses. The latter circumstance causes a collective percentage of more than 100 .

The distribution of offenses depending on their nature is presented in table 2 .

Table 2 - The nature of violent acts

\begin{tabular}{l|c|c}
\hline \multicolumn{1}{c|}{ The nature of offenses } & \multicolumn{2}{c}{ Amount (abs/\%) } \\
\hline $\begin{array}{l}\text { Verbal abuse (obscene language, offensive expressions, including sexual, humiliating } \\
\text { phrases, obscene comments) }\end{array}$ & 78 & 50.32 \\
\hline $\begin{array}{l}\text { Threat of violence (warnings of intents to harm, harass, physical intimidation, threats } \\
\text { with weapon) }\end{array}$ & 57 & 36.77 \\
\hline Symbolic violence (throwing furniture, utensils, blows into the wall) & 5 & 3.23 \\
\hline Forcible holding, hostage taking & 1 & 0.65 \\
\hline Physical attack (blows, pushes, bites) & 10 & 6.45 \\
\hline Confrontation beyond direct contact with the patient (tracking, phone calls, letters) & 2 & 1.29 \\
\hline Damage to property, vehicles & 2 & 1.29 \\
\hline Total & 155 & 100 \\
\hline
\end{tabular}

The results indicate that 78 incidents occurred during one year when emergency medical workers became victims of verbal abuse. 10 medical workers were physically attacked, which is $6.45 \%$.

It is noteworthy that, most often, emergency medical workers with experience of up to 5 years were subjected to aggressive actions $-61.29 \%$ of all victims. The conducted correlation analysis confirmed the relation between the length of service and the number of offenses. Positive strong correlation relations $(\mathrm{r}=0.98 ; \mathrm{p}<0.01)$ were determined for employees with work experience up to 5 years. In the same group, most cases of the use of physical impact were observed $-18.75 \%$. It is likely that after 5-7 years of work, doctors and paramedics develop their own, individual crisis resolution strategies.

Most often, the reasons for the aggressive behavior of a patient or third parties were the waiting time of a medical worker and a suspicion of incompetence.

Describing offenders, respondents noted that in $87(56.13 \%)$ cases, inappropriate behavior was due to alcohol intoxication, in $14(9.03 \%)$ - drug intoxication, in $36(23.23 \%)$ patients there were signs of acute or chronic mental diseases. In 18 $(11.61 \%)$ cases, the patient's aggressive condition was the result of his illness (acute pain, hypoxia, etc.). These were unconscious reflexive manifestations of aggression that could be managed by persuasion and the use of soothing painkillers.

We determined that the incidents occurred mainly at the patients' place of residence $(57.42 \%)$, in the street $(27.74 \%)$, at the reception department of the medical institution $(9.03 \%)$ and during transportation $(5.81 \%)$.

In $23(14.84 \%)$ cases, the police were involved to resolve the conflict. Mainly, medical workers with work experience of more than 10 years (31 calls, or $52.54 \%)$. In $132(85.16 \%)$ cases of aggression by patients or third parties, emergency medical personnel did not report the authorities.

The main reasons why the respondents did not inform the administration or law enforcement authorities about the incident occurred are presented in table 3 .

As follows from the table, in most cases, respondents consider conflict situations to be an integral part of their work $(54.55 \%)$.

In the course of further research, we decided to find out what measures, according to the respondents, will make it possible to change the situation for the better (table 4). 
Table 3 - Reasons why health workers did not report the incidents

\begin{tabular}{l|c|c}
\multicolumn{1}{c|}{ Reasons } & \multicolumn{2}{c}{$\begin{array}{c}\text { Number of respondents } \\
\text { (abs/\%) }\end{array}$} \\
\hline They consider conflict situations as an integral part of work & 72 & 54.55 \\
\hline Lack of free time & 34 & 25.76 \\
\hline Fear of disapproval by the administration & 4 & 3.03 \\
\hline They feel guilty of a conflict & 2 & 1.52 \\
\hline $\begin{array}{l}\text { They do not believe in the possibility of prosecuting persons who have committed } \\
\text { violent acts }\end{array}$ & 17 & 12.88 \\
\hline Lack of knowledge of the reporting form and legal protection & 3 & 2.27 \\
\hline Total & 132 & 100 \\
\hline
\end{tabular}

Table 4 - Suggestions of emergency medical workers as for ways for normalizing the situation

\begin{tabular}{l|c|c}
\multicolumn{1}{c|}{ Ways of normalizing of the situation } & \multicolumn{2}{c}{$\begin{array}{c}\text { Number of suggestions } \\
\text { (abs/\%) }\end{array}$} \\
\hline Improving the law support and judicial assistance & 19 & 14.96 \\
\hline Complete staffing of teams & 45 & 35.43 \\
\hline Providing with personal protective equipment & 31 & 24.41 \\
\hline Providing with video recording devices & 3 & 2.36 \\
\hline Providing with firearms & 1 & 0.79 \\
\hline Rising of moral standards of the population & 17 & 13.39 \\
\hline Work in co-operation with the police & 11 & 8.66 \\
\hline Total & 127 & 100 \\
\hline
\end{tabular}

The data shown in table 4 indicate the following: $35.43 \%$ of the workers believe that the situation can be improved by complete staffing and formation of mixed-type brigades (male / female). Almost a third of the questioned medical workers $(24.41 \%)$ indicated the need to provide personal protective equipment (stun guns, gas sprays),

\section{Conclusions}

1. As a result of the studies, it was found that $74.8 \%$ of emergency medical care workers became victims of violent and aggressive actions at the workplace throughout the year, which is in line with global trends.

2. The development of a strategy and making decisions to ensure protection of the life and health of emergency medical care workers should be another $14.96 \%$ of the respondents want better legal support and judicial assistance.

When determining the level of security experienced by the workers during a call, $46.46 \%$ of the respondents $(43.75 \%$ of men and $49.21 \%$ of women) noted that they do not feel safe (average score $4.57 \pm 0.21$ ).

carried out at the state legislative level with the possibility of their practical implementation.

3. The curriculum for training of emergency medical specialists should include the mandatory course "Effective Communication in Conflict Situations" with the conduct of trainings to model various incidents and develop possible options for protection behavior.

\section{Conflict of interest}

The authors declare no conflict of interest. 


\section{Відомості про авторів}

Шкатула Юрій Васильович, доктор медичних наук, професор, Медичний інститут Сумського державного університету, зав. курсом невідкладних станів кафедри загальної хірургії, радіаційної медицини та фтизіатрії (0995486171, у.shkatula@med.sumdu.edu.ua);

Бадіон Юрій Олексійович, кандидат медичних наук, Медичний інститут Сумського державного університету, асистент кафедри загальної хірургії, радіаційної медицини та фтизіатрії (0994581857, y.badion@med.sumdu.edu.ua);

Новіков Максим Володимирович, КЗ СОР «Сумський обласний центр екстреної медичної допомоги та медицини катастроф», заступник директора (maksim72nov@ukr.net);

Хижня Ярослава Володимирівна, кандидат медичних наук, Медичний інститут Сумського державного університету, асистент кафедри загальної хірургії, радіаційної медицини та фтизіатрії (y.khyzhnia@med.sumdu.edu.ua)

\section{References}

1. D’Aubarede C, Sarnin P, Cornut PL, Touzet S, Duclos A, Burillon C et al. Impacts of users' antisocial behaviors in an ophthalmologic emergency department-a qualitative study. J Occup Health 2016; 58:96-106. doi: 10.1539/joh.15-0184-FS

2. Gormley MA et al. A National Description of Violence toward Emergency Medical Services Personnel. Prehospital Emergency Care 2016; 4:439-447. doi: 10.3109/10903127.2015.1128029

3. Hogarth KM, Beattie J, Morphet J. Nurses' attitudes towards the reporting of violence in the emergency department. Australas Emerg Nurs J 2016; 19:75-81.

doi: 10.1016/j.aenj.2015.03.006

4. Edward K, Ousey K, Warelow P, Lui S. Nursing and aggression in the workplace: a systematic review. $\mathrm{Br} J$ Nurs 2014; 23:653-9. doi: 10.12968/bjon.2014.23.12.653

5. Maguire BJ, O'meara $\mathrm{P}$, O'neill BJ, Brightwell R. Violence against emergency medical services personnel: A systematic review of the literature. American journal of industrial medicine 2018; 2:167-180. doi: 10.1002/ajim.22797

6. Pourshaikhian M, Gorji HA, Aryankhesal A, Khorasani-Zavareh D, Barati A. A systematic literature review: workplace violence against emergency medical services personnel. Arch Trauma Res 2016; 5:213-24. doi: 10.5812/atr.28734
7. Ramacciati N, Ceccagnoli A, Addey B. Violence against nurses in the triage area: an Italian qualitative study. Int Emerg Nurs 2015;23:274-80. doi: 10.1016/j.ienj.2015.02.004

8. Holovanova IA, Kasinets SS, Krasnova OI, Khorosh MV. The modern situation with emergency medical care in Ukraine in the conditions of reform: Problems and perspectives. Emerg Med Serv 2018; 2:63-67.

9. Morphet J, Griffiths D, Plummer V, Innes K, Fairhall R, Beattie J. At the crossroads of violence and aggression in the emergency department: perspectives of Australian emergency nurses. Aust Health Rev 2014; 38:194-201.

10. Weiß J. Violence against medical assistants. Dtsch Arztebl Int 2015; 112(43):736. doi: 10.3238/arztebl.2015.0736a

11. Gillam SW. Nonviolent crisis intervention training and the incidence of violent events in a large hospital emergency department: an observational quality improvement study. Adv Emerg Nurs $\quad J \quad 2014 ; \quad 36: 177-88$. doi: 10.1097/TME.0000000000000019

12. Knowles E, Mason SM, Moriarty F. 'I'm going to learn how to run quick': exploring violence directed towards staff in the emergency department. Emerg Med J 2013; 30:926-31.

13. Wolf LA, Delao AM, Perhats C. Nothing changes, nobody cares: understanding the experience of emergency nurses physically or verbally assaulted while providing care. J Emerg Nurs 2014; 
40:305-10.

doi: 10.1016/j.jen.2013.11.006

14. Law of Ukraine "On Emergency Medical Aid". Revision from 09.12.2015. Retrieved from:

http://zakon.rada.gov.ua/laws/show/5081-17.
15. Mullan B, Badger F. Aggression and violence towards staff working with older patients. Nurs. Standart 2007; 21(27):35-38.

(received 05.11.2019, published online 29.12.2019)

(одержано 05.11.2019, опубліковано 29.12.2019) 